\title{
The Contributions of School Principals as Constructivist Leaders to Their Schools' Organizational Change
}

\author{
M. Cevat YILDIRIM ${ }^{1}$ \\ Ahmet KAYA ${ }^{2}$ \\ 'College of Education, Van Yüzüncü Yıl University, Van, Turkey \\ Email:mcevatyildirim@gmail.com Tel:+904324445065 \\ ${ }^{\circ}$ College of Education, Harran University, Şanliurfa, Turkey \\ Email:ahmetkaya@harran.edu.trTel:+904143183466
}

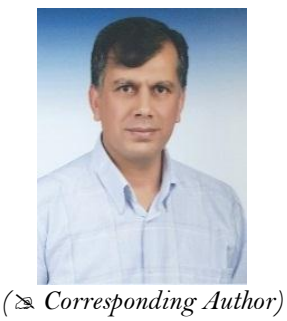

\section{Abstract}

The purpose of this paper is to determine the contributions of school principals as constructivist leaders in their schools' according to teachers' opinions. This study is qualitative research based on a phenomenological model. Researchers collected data through the semi-structured interview method. The study group was determined by a maximum variation sampling and composed of 13 teachers working in the province of Şanlıurfa, Turkey. Researchers analyzed the data using the content analysis method. The research found that school principals as constructivist leaders contributed to their schools' organizational change. These contributions are collected under six categories: learning and teaching, sharing leadership, communication and interaction, a safe school environment, encouragement, and strategic planning. This paper makes two contributions to extant literature on this topic. Firstly, this paper facilitates the understanding of constructive leadership roles among principals. Secondly, this paper helps us determine the contributions of school principals as constructive leaders to the organizational change in their school, thus contributing to a better understanding of school leadership.

Keywords: Constructivist leadership, Constructivist learning approach, Organizational change, Principal, School improvement, Sharing leadership.

Citation | M. Cevat YILDIRIM; Ahmet KAYA (2019). The Contributions of School Principals as Constructivist Leaders to Their Schools' Organizational Change. Asian Journal of Education and Training, 5(1): 1-7.

History:

Received: 21 August 2018

Revised: 24 September 2018

Accepted: 26 October 2018

Published: 29 November 2018

Licensed: This work is licensed under a Creative Commons

Attribution 30 License (cc)

Publisher: Asian Online Journal Publishing Group
Contribution/Acknowledgement: Both authors contributed to the conception and design of the study.

Funding: This study received no specific financial support.

Competing Interests: The authors declare that they have no conflict of interests.

Transparency: The authors confirm that the manuscript is an honest, accurate, and transparent account of the study was reported; that no vital features of the study have been omitted; and that any discrepancies from the study as planned have been explained.

Ethical: This study follows all ethical practices during writing.

\section{Contents}

1. Introduction

2. Method

3. Findings

4. Conclusion and Discussion 


\section{Introduction}

Schools are dynamic institutions affected by changes in education and try to comply with these changes. One of the most important factors affecting the schools is the constructivist learning approach. This approach and other developments in education led to changes in school management applications (Yıldırım, 2012).

Constructivism is a learning approach that puts an active emphasis on the learner's taking responsibility during the learning process and on the construction of information by the learner himself or herself (Brooks and Brooks, 1999; Perkins, 1999; Özden, 2005; Yıldırım and Dönmez, 2008). First applied in the field of education in England in 1989 (Pon, 2001) constructivism is now used in more than thirty countries (Güneş, 2007). Some of the countries who use this approach are Australia, Canada, New Zealand, Spain, the UK, the U.S. (Matthews, 2000) and Turkey (Yildirim, 2012).

This approach has also influenced many schools' management and leadership philosophies. With the advent of the constructivist learning approach, constructivist management and leadership ideas came to the fore (Brooks and Brooks, 1999; Lambert et al., 2002; Shapiro, 2002;2003). Some researchers studied constructivist management and leadership (Shapiro, 2002;2003; Lambert, 2003; Isaacson, 2004; Ylldırım, 2012;2014). These studies were generally discussed from teachers' and students' perspectives, however. There have not been any studies in the literature that discuss the constructivist leadership from school principals' perspective and the contributions this leadership makes to effect organizational change in schools.

Actually, dealing with this issue as principals implement it is extremely important. According to Fullan (2007) principals have a key role in the improvement of a school. School principals are one of the most important actors in accomplishing new applications. For this reason, the contributions of school principals as constructivist leaders to their schools' organizational change is worthy of being examined. The purpose of this study is to determine the contributions of principals' leadership to their schools' organizational change to constructivism from the teachers' perspective.

\subsection{Constructivist Leadership}

"Leadership" is a complex term-and an elusive one. Diverse definitions exist, some of them similar, others not. (Sisman, 2002; Lambert, 2003; Hoy and Miskel, 2008). In common parlance, leadership means "moving an organization's members towards determined goals (Hodgkinson, 2008). In management, thought leaders have developed various theories and practices in leadership, such as distributed leadership, moral leadership, transformational leadership, and instructional leadership (Celik, 2000; Celep, 2004; Harris, 2008; Hoy and Miskel, 2008; Gorton and Alston, 2009; Glickman et al., 2010).

Constructivism has required management theorists to re-examine the notion of leadership and create a new school of thought, constructivist leadership. As it related to the teaching profession, constructivist leadership consists of both reciprocal processes and spiritual concepts. Thus, it leads to a shared purpose in learning through enabling related participants to construct meanings and embrace reciprocity, equity, meaning, learning, responsibility, and community. It is based on constructivist learning principles (Lambert, 2002a), such as active participation, encouragement, facilitation, and shared responsibility (Brooks and Brooks, 1999; Lambert et al., 2002; Fosnot, 2005). Accordingly, constructivist leadership also requires reciprocal processes that involve active participation, shared purposes and values, sharing responsibility, encouragement, and facilitation.

Constructivist leadership overlaps or matches with distributed leadership, transformational leadership, and moral leadership in some respects, but it is a different leadership style since it rests on a foundation of constructivism. With this overlap, it is often difficult to draw sharp lines to define various leadership styles.

\subsection{Organizational Change and Principals as Constructivist Leaders}

Constructivist leadership is a key ingredient in successful constructive classes and schools. Especially, it is extremely important for school principals to carry out their leadership roles in a constructionist manner. These leaders perform constructivism's requirements in general terms and those of constructivist leadership as they perform specific tasks.

Constructivist leaders are flexible and open to change. They welcome diverse opinions (Bauch, 2001). As constructivist leaders, principals become powerful initiators of change (Lambert and Walker, 2002) becoming agents of change themselves. They also operate as organizational troubleshooters (Shapiro, 2002).

The real keys for change are for these principals to reconsider cultural norms and values (Lambert and Walker, 2002; Schlechty, 2005). School leaders try to find ways to encourage school stakeholders as partners for change throughout the process (Lambert and Walker, 2002) through paying attention to flexibility, diversity (Bauch, 2001; Lambert, 2002a) partnership with parents, and evolution of thought (Lambert, 2002a). Thus, they encourage all to take responsibility as a requirement of their school's cultural norm (Thompson et al., 2004).

Leaders in constructive organizations that take on the role of a pioneering organization for change value sharing leadership and distributing authority among employees, regarding these as normal behaviors (Lambert and Gardner, 2002; Szabo and Lambert, 2002; Schlechty, 2005). Constructive leaders realize effective decision-making with the active participation of their partners in a democratic, righteous way (Lambert and Gardner, 2002; Shapiro, 2002). Participation in the decision-making process leads others to internalize decisions and thus develops a shared feeling for their collective responsibilities (DeVries and Zan, 2005). They encourage the school's stakeholders and give incentives to establish a school culture that fosters shared meaning since, after all, constructivism-by its nature--includes dialogue, conversation, inquiry, and action (Lambert and Walker, 2002).

Schools establish their visions and missions through conversations (Bauch, 2001). As constructivist leaders, their principals consider conversation as an important component of constructive leadership (Cooper, 2002; Lambert, 2002) accepting it as a key component in constructive change (Lambert, 2002). Constructivist leaders see vision and values as the guiding compass of change (Lambert and Walker, 2002). So, constructivist leaders cooperate with society and school stakeholders to determine unifying goals, a strong vision, mission statements, and shared values (Lambert and Walker, 2002). In a school with constructivist leadership, all school partners get respect and acceptance. The school's leaders have clear communication with the school's stakeholders, valuing 
different perspectives and giving opportunities for all of the partners to express their opinions (Shapiro, 2002;2003).

Therefore, principals have an essential role in the success of their schools (Thompson et al., 2004). Constructive leaders contribute to the establishment of a safe learning environment where partners and employees are motivated, fostered, and encouraged to take risks; and where their social and psychological needs are meet (Shapiro, 2003). They fulfill their role as facilitators and encourage school stakeholders and partners so that managerial and educational activities happen according to a constructivist paradigm.

\section{Method}

Phenomenology, a qualitative research design, was used in this study. Phenomenological design is a research model that aims to study the cases or facts about which researchers are not well informed or do not have a detailed understanding (Yildirim and Simsek, 2005).

\subsection{Study Group}

The study group consists of 13 teachers in various schools in Turkey's Şanlıurfa province. The teachers in the study group were determined through a maximum variation sampling method. Teachers in the study group include three teachers in primary school, six teachers in middle school, and four teachers in high school. Seven of these teachers are male and the remaining six teachers are female (Table-1).

Table-1. Information of the teachers in the study group

\begin{tabular}{l|l|l}
\hline Variables & & $\mathbf{f}$ \\
\hline \multirow{4}{*}{ Place of duty } & Village & 3 \\
\cline { 2 - 3 } & Town Center & 2 \\
\cline { 2 - 3 } & City Center & 8 \\
\hline \multirow{2}{*}{ Gender } & Male & 7 \\
\cline { 2 - 3 } & Female & 6 \\
\hline \multirow{2}{*}{ School Type } & Primary School & 3 \\
\cline { 2 - 3 } & Middle School & 6 \\
\cline { 2 - 3 } & High School & 4 \\
\hline
\end{tabular}

\subsection{Data Collection Instruments}

Data were collected through the semi-structured interview method. Semi-structured interviews ranging from 30 to 60 minutes in length were conducted in the first term of the 2012-2013 academic year. An audio recording device was not used in the interviews since teachers in the study group might have felt uncomfortable with audio recordings. Instead, note-taking was the preferred method to collect data. These semi-structured interviews were based on this question: What are the contributions of principals as constructive leaders in a school' organizational change?

\subsection{Data Analysis}

The data were analyzed through the content analysis technique. Themes were determined by taking the stages of content analysis into account. Also, quotations taken from teachers' views were given in the content analysis. Code numbers such as $\mathrm{T} 1, \mathrm{~T} 2 \ldots . . \mathrm{T} 13$ were given to each teacher in the study group and related explanations were made.

\subsection{Validity and Reliability}

Some of the transactions the study conducted to increase the validity and reliability of this research are as follows: (i) Four related experts' opinions were taken concerning the interview questions. (ii) Before the actual interviews, a preliminary practice of a semi-structured interview was conducted with one of the teachers. (iii) The member checking technique was employed. (iv) Researchers coded each of the notes independently. (v) The reliability of the study's coding was calculated by a formula: [reliability $=$ number of agreements $/$ total number of agreements + disagreements] which was suggested by Miles and Huberman (1994). In the coding of semistructured interview data, there was found 75 percent or more correspondence between the two coders. The correspondence percentages calculated for six themes of the study between two coders are as follows, respectively: $100 \%, 75 \%, 100 \%, 83 \%, 80 \%$, and $100 \%$.

\section{Findings}

The contributions of school principals as constructivist leaders in the organizational change in their schools are categorized into six categories (Table-2). According to these findings, the teachers that participated in the interviews think that school principals as constructive leaders contribute to their schools' organizational change in the following categories: learning, teaching, sharing leadership, communication, interaction, a safe school environment, encouragement, and strategic planning.

\subsection{Learning and Teaching}

The contributions of school principals as constructivist leaders in learning and teaching can be listed under three items. The contribution with one of the highest frequencies was "promoting teachers for their professional development." "Supporting constructive learning applications and establishing a constructive learning environment" also appeared with high frequency. Some of the teachers' views concerning this theme are as follows: "Constructivist leaders support teachers so that they can realize their learning activities in accordance with a constructivist approach. Thus, they contribute to the organizational change of their schools with regards to learning activities" (T10). "Constructivist school principals help teachers in creating constructive environments" 
(T11). "Constructivist principals encourage teachers to develop themselves professionally in their jobs. They believe teachers need to develop themselves in their professions to keep up with the change" (T3).

Table-2. Teacher opinions about the contributions of school principals as constructivist leaders in their schools' organizational chan ge.

\begin{tabular}{|c|c|c|}
\hline Category name & Coded Teacher Opinions & f \\
\hline \multirow{3}{*}{ Learning and teaching } & Promoting teachers for their professional development & 13 \\
\hline & Supporting constructivist learning applications & 12 \\
\hline & Establishing a constructivist learning environment & 11 \\
\hline \multirow{4}{*}{ Sharing leadership } & Active participation of partners or stakeholders in making decisions & 13 \\
\hline & Transfer or distribution of authority & 9 \\
\hline & Sharing responsibility & 7 \\
\hline & Building a sense of responsibility & 7 \\
\hline \multirow{3}{*}{ Communication and interaction } & Establishing clear communication & 13 \\
\hline & Giving place to dialog and discussion & 13 \\
\hline & Building interaction & 12 \\
\hline \multirow{6}{*}{ A safe school environment } & Establishing trust in stakeholders or partners & 13 \\
\hline & Building a safe school environment & 9 \\
\hline & Acceptance of stakeholders or partners & 8 \\
\hline & Respecting stakeholders & 8 \\
\hline & Establishing an environment based on justice & 8 \\
\hline & Accepting the differences & 6 \\
\hline \multirow{5}{*}{ Encouragement } & Pioneering change & 10 \\
\hline & Accepting change & 10 \\
\hline & Depending on flexibility & 9 \\
\hline & Motivating the stakeholders & 9 \\
\hline & Realizing a role as a facilitator & 9 \\
\hline \multirow{3}{*}{ Strategic planning } & Building shared goals & 10 \\
\hline & Building a shared vision and mission & 8 \\
\hline & Building shared values and beliefs & 5 \\
\hline
\end{tabular}

Source: Obtained from primary data.

\subsection{Sharing Leadership}

The contributions of school principals as constructivist leaders in sharing leadership are listed under four items. The item with the highest frequency is "active participation of partners or stakeholders in decision making." Also, it "transfer or distribution of authority:" also occurred frequently. Some of the teachers' views concerning this theme were the following: "Constructivist school leaders pass on their authorities to others when required, by which they prepare their subordinates for leadership" (T2). "Constructivist principals encourage all people in school to take part in the decision-making process and thus contribute to the establishment of a positive school environment" (T1). "Constructivist principals give importance to a school culture in which responsibility is shared and a sense of responsibility is developed" (T12).

\subsection{Communication and Interaction}

School principals as constructive leaders contribute to organizational change through their communication and interaction. All the teachers participating in the interviews think that giving place to dialog and discussion, and sharing authority are the contributions of school principals as constructivist leaders to the organizational change in their schools. Here are given some views concerning this theme: "Constructivist leaders establish strong and clear communication among school employees" (T5). "Constructive principals take the lead in building an environment where interaction is fostered among all the school's stakeholders" (T8). "Building an environment of interaction, dialog, and discussion is one of the most important factors to affect success in a school" (T13).

\subsection{A Safe School Environment}

The contributions of school principals as constructive leaders in creating a safe school environment are seen listed under six items. All the teachers participating in the interviews think establishing trust in stakeholders or partners is important for a school's organizational change. Some of the teachers' opinions about this theme can be listed as follows: "Constructivist school principals pay attention to building a safe school environment and do not allow gossip and rumors: an environment where employees trust each other and have confidentiality is fostered" (T5). "School principals show tolerance for different beliefs, thinking, and opinions" (T4). "Constructive leaders strive for building an environment that will help both teachers and students express their emotion and opinions easily." (T9). "Constructivist school leaders let all others feel that they treat all the stakeholders and partners equally and fairly in the same manner" (T7). "A constructive leader tries to make all the personnel feel valuable" (T8).

\subsection{Encouragement}

Teachers think that school principals as constructivist leaders contribute to organizational change in five ways through encouragement. One of the items with the highest frequency is "pioneering change" and the other one is "accepting change." Other related views include the following: "Constructivist leaders are open to change" (T6). "They encourage stakeholders to adapt to change and pioneer that change." (T10). "Constructivist principals are flexible and realize their role as a facilitator. They do not make things difficult" (T1). "One of the foremost tenets of constructive leadership is to motivate the school's stakeholders" (T13). 


\subsection{Strategic Planning}

The contributions of school principals as constructive leaders in their schools' organizational change through strategic planning are listed under three items. The response with the highest frequency is "building shared goals." Other teachers' views include the following: "Constructivist leaders give importance to shared values accepted by all stakeholders" (T2). "Shared vision, mission, and values positively affect employees' commitment to the school and their sense of belonging" (T12). "Constructive school leaders pay attention to building shared goals that are key ingredients in both strategic planning and increasing the school's success" (T3).

\section{Conclusion and Discussion}

The results of this study show school principals as constructivist leaders contribute to organizational change in their schools. The results reveal that constructive leaders have an important role in facilitating organizational change in their schools. The contributions of school principals as constructivist leaders into schools' organizational change fall under six categories.

\subsection{Learning and Teaching}

School principals as constructivist leaders contribute to a school's organizational change by promoting teachers' professional development, supporting constructive learning applications, and establishing a constructive learning environment. One of the basic tenets of constructive schools is to promote the professional development of all school employees and teachers, construct related policies, and apply these principles throughout their schools (Lambert and Gardner, 2002). Teachers' professional development also has a vital role to play in schools (Yıldırım, 2012a). Encouraging teachers to undergo professional development as a part of their job is also an important issue (Thompson et al., 2004). Therefore, constructive leaders support both continuous development of a school's employees and building a constructive learning environment (Lambert et al., 2002).

\subsection{Sharing Leadership}

Another result of the study is that school principals as constructivist leaders contribute to their schools' organizational change by enabling all stakeholders to participate actively in the decision-making process--sharing authority and responsibility during the process. Active participation in decision-making and sharing leadership affects teachers positively in their commitment to the organization (Hulpia et al., 2009). Constructivist leaders that share their power and allow their employees to take part in decision-making develop a sense of shared responsibility (Lambert et al., 2002; DeVries and Zan, 2005). This situation affects a school's organizational change positively. According to Szabo and Lambert (2002) constructive leaders contribute to positive change in both individuals' and organizations. Leadership also affects an organization's success. Therefore, every organization should include at least some opportunities for shared leadership (Kocolowski, 2010).

\subsection{Communication and Interaction}

According to another result of the study, school principals as constructivist leaders contribute to organizational change in their schools by establishing open communication, building interaction, and promoting dialog and discussion. One of the most important tenets of constructivism is inquiry-the ability to question (Brooks and Brooks, 1999; Lambert and Walker, 2002; Gould, 2005). For that reason, constructive leaders give importance to an environment that creates opportunities for dialog and turns communication into interaction (Brooks and Brooks, 1999; Güneş, 2007; Yıldırım, 2012). Dialog and conversation form the base of both constructive leadership and constructive change (Lambert, 2002). Research shows that there is a direct relationship between principals' communication skills and their school's culture (Simsek, 2003). Establishing conversation and interaction according to constructivist principles help principals guide their schools' culture to undergo positive change.

\subsection{A Safe School Environment}

School principals as constructivist leaders contribute to organizational change through establishing a safe school climate, respecting stakeholders or partners, valuing differences, and embracing justice as a base value. According to Shapiro, an environment where all partners are encouraged to take risks and create an environment in which personal secrets can be shared is a safe school. Constructive leaders must realize their role as a facilitator role as they strive to build such an environment. To do so, they must show respect, value different opinions, treat all stakeholders equally, and believe in the importance of stakeholders' contributions (Shapiro, 2003). A healthy school climate is related to a safe school environment. The prerequisite of a safe school environment is to take the school climate in a more positive direction (Calı et al., 2011). Therefore, the struggles of a constructive leader to create a safe school environment contribute to the school's change in a positive way.

\subsection{Encouragement}

Another result of the study shows that school principals as constructivist leaders pioneer change, accept change, become more flexible, motivate the stakeholders, and realize their role as a facilitator, thus contributing to the school's organizational change. A school's principal is one of the most important factors in that effect change in a school culture (Celik, 2000a; Fullan, 2007). Constructive leaders that want to realize organizational change must be flexible (Bauch, 2001; Ozden, 2002), pioneer change (Lambert and Walker, 2002) and be open to change (Celik, 2000a; Bauch, 2001). Therefore, it is crucial for school leaders to embrace change, encourage people as they undergo change (Erdoğan, 2002), and realize their facilitative and inclusive role (Shapiro, 2003; Fullan, 2007) so that change can be accomplished. 


\subsection{Strategic Planning}

Another result of the study is that school principals as constructivist leaders contribute to their schools' organizational change by establishing shared goals, visions, missions, values, and beliefs. Shared visions, missions, goals (Demirel and Karadal, 2007) beliefs, and values are essential parts of an organization's culture (Demirel and Karadal, 2007; Sisman, 2007). These constituents form the base of strategic planning (Şahin and Aslan, 2008). School leaders must change their school's culture to realize organizational change (Celik, 2000a; Schlechty, 2005). Shared beliefs and values have an important function in organizational change (Schlechty, 2005). Shared visions affect the changing relationship between an organization and its employees, the increase in organizational commitment, and the establishment of a shared identity in a positive way (Senge, 2002). For that reason, constructive leaders consider shared visions, missions, goals, and values as indispensable parts of organizational change (Lambert and Walker, 2002; Lambert and Gardner, 2002).

\section{Recommendations}

Constructive leadership has been at the top of many schools' agendas in recent years. There have been some studies conducted concerning teachers' constructivist leadership. However, similar studies should be done for school principals regarding their roles in constructivist leadership.

This study used the qualitative research method to arrive at its conclusion and recommendations. There is a need for both quantitative and qualitative research related to this topic. In-service training or educational activities that promote constructive leadership and build constructive leaders must occur for both teachers and principals to facilitate positive organizational change.

\section{References}

Bauch, P.A., 2001. School-community partnerships in rural schools: Leadership, renewal, and a sense of place. Peabody Journal of Education, 76(2): 204-221. Available at: https://doi.org/10.1207/s15327930pje7602_9.

Brooks, J.G. and M.G. Brooks, 1999. In search of understanding: The case for constructivist classrooms. Alexandria, VA: ASCD.

Calık, T., T. Kurt and C. Calık, 2011. School climate in creating safe school: A conceptual analysis. Pegem Journal of Education and Training, 1(4): 73-84. Available at: https://doi.org/10.14527/c1s4m8.

Celep, C., 2004. Transformational leadership. Ankara: Anı.

Celik, V., 2000. Educational leadership. 2nd Edn., Ankara: Pegem A.

Celik, V., 2000a. School culture and management. 2nd Edn., Ankara: Pegem A.

Cooper, J.E., 2002. Constructivist leadership: Its evolving narrative. The constructivist leader. 2nd Edn., New York: Teachers College. pp: $112-126$.

Demirel, Y. and H. Karadal, 2007. An investigation of organization culture upon the usage of individual skills in the organization. Journal of Faculty of Economics and Administrative Sciences, 12(3): 253-270.

DeVries, R. and B. Zan, 2005. A constructivist perspective on the role of the sociomoral atmosphere in promoting children's development. In C. T. Fosnot (Ed.), Constructivism: Theory, perspectives, and practice. 2nd Edn., New York: Teachers College. pp: 132-149

Erdoğan, I., 2002. Change management in education. Ankara: Pegem A.

Fosnot, C.T., 2005. Constructivism: Theory, perspectives, and practice. 2nd Edn., New York: Teachers College.

Fullan, M., 2007. The new meaning of educational change. 4th Edn., New York: Teachers College.

Glickman, C.D., S.P. Gordon and J.M. Ross-Gordon, 2010. Supervision and instructional leadership. 8th Edn., Boston, MA: Pearson Education.

Gorton, R. and J.A. Alston, 2009. School leadership and administration: Important concepts, case studies, \& simulations. 8th Edn., New York: McGraw-Hill.

Gould, J.S., 2005. A constructivist perspective on teaching and learning in the language arts. In C. T. Fosnot (Ed.), Constructivism: Theory, perspectives, and practice. 2nd Edn., New York: Teachers College Press. pp: 99-109.

Güneş, F., 2007. Classroom management with constructivist approach. 1st Edn., Ankara: Nobel Publication Distribution.

Harris, A., 2008. Distributed leadership: According to the evidence. Journal of Educational Administration, 46(2): 172-188. Available at: https://doi.org/10.1108/09578230810863253.

Hodgkinson, C., 2008. Administrative philosophy: Values and motivations in administrative life. (I. Anıl \& B. Doğan, Trans. Eds.). İstanbul: Beta.

Hoy, W.K. and C.G. Miskel, 2008. Educational administration: Theory, research, and practice. 8th Edn., New York: McGraw-Hill.

Hulpia, H., G. Devos and H. Van Keer, 2009. The influence of distributed leadership on teachers' organizational commitment: A multilevel approach. The Journal of Educational Research, 103(1): 40-52. Available at: https://doi.org/10.1080/00220670903231201.

Isaacson, L.S., 2004. Teachers' perceptions of constructivism as an organizational change: A case study. Doctoral Dissertation, University of South Florida.

Kocolowski, M.D., 2010. Shared leadership: Is it time for a change. Emerging Leadership Journeys, 3(1): 22-32.

Lambert, L., 2002. Leading the conversations. The constructivist leader. 2nd Edn., New York: Teachers College. pp: 63-88.

Lambert, L., 2002a. Toward a deepened theory of constructivist leadership. The constructivist leader. 2nd Edn., New York: Teachers College. pp: 34-62.

Lambert, L., 2003. Leadership redefined: An evocative context for teacher leadership. School Leadership \& Management, 23(4): 421-430. Available at: https://doi.org/10.1080/1363243032000150953.

Lambert, L. and D. Walker, 2002. Constructing school change-school stories. The constructivist leader. 2nd Edn., New York: Teachers College. pp: 127-163.

Lambert, L., D. Walker, D.P. Zimmerman, J.E. Cooper, M.D. Lambert, M.E. Gardner and M. Szabo, 2002. The constructivist leader. 2nd Edn., New York: Teachers College Press.

Lambert, M.D. and M.E. Gardner, 2002. The school district as interdependent learning community. The constructivist leader. 2nd Edn., New York: Teachers College. pp: 164-203.

Matthews, M.R., 2000. Constructivism in science and mathematics education. In D. C. Phillips (Ed.), National Society for the Study of Education 99th Yearbook. Chicago: University of Chicago. pp: 161-192.

Miles, M.B. and A.M. Huberman, 1994. Qualitative data analysis: An expanded sourcebook. 2nd Edn., Thousand Oaks, California: Sage.

Ozden, Y., 2002. Transformation in education: New values in education. 4th Edn., Ankara: Pegem A.

Özden, Y., 2005. Learning and teaching. 7 th Edn., Ankara: Pegem A.

Perkins, D., 1999. The many faces of constructivism. Educational Leadership, 57(3): 6-1 1

Pon, N., 2001. Constructivism in the secondary mathematics classroom. EGallery, 3(2). Available from http://www.ucalgary.ca/ egallery.

Şahin, S. and N. Aslan, 2008. A qualitative study on the opinions of secondary school principals regarding strategic planning. Gaziantep University Journal of Social Sciences, 7(1): 72-189.

Schlechty, P.C., 2005. Shaking up the school house (Y. Özden, Trans.). Ankara: Nobel.

Senge, P.M., 2002. The fifth discipline (A. İldeniz \& A. Doğukan, A. Trans.). İstanbul: Yapı Kredi.

Shapiro, A., 2002. Leadership for constructivist schools. Lanham: The Scarecrow.

Shapiro, A., 2003. Case studies in constructivist leadership and teaching. Lanham: The Scarecrow. 
Simsek, Y., 2003. The relationship between school principals' communication skills and school culture [the relationship between the school principals]. Unpublished Doctoral Dissertation, University of Anatolia, Eskisehir, Turkey.

Sisman, M., 2002. Instructional leadership. Ankara: Pegem A.

Sisman, M., 2007. Organizations and cultures. 2nd Edn., Ankara: Pegem A.

Szabo, M. and L. Lambert, 2002. The preparation of new constructivist leaders. The constructivist leader. 2nd Edn., New York: Teachers College. pp: 204-238.

Thompson, S.C., L. Gregg and J.M. Niska, 2004. Professional learning communities, leadership, and student learning. Research in Middle Level Education Online, 28(1): 1-15.

Yildirim, A. and H. Simsek, 2005. Qualitative research methods in social sciences. 5th Edn., Ankara: Distinguished.

Yildırım, M.C., 2012. Analysis of teachers' constructivist learning environment management skills in terms of some variables. Electronic Journal of Social Sciences, 11(42): 79-92.

Yıldirım, M.C., 2014. Developing a scale for constructivist learning environment management skills. Eurasian Journal of Educational Research, 14(54): 1-18. Available at: https://doi.org/10.14689/ejer.2014.54.1.

Yıldırım, M.C., 2012a. A study on contribution of the basic training course to the professional development of probationary teachers. Educational Sciences in Theory and Practice, 12(3): 1867-1886.

Yıldırım, M.C. and B. Dönmez, 2008. A study about the effects of constructivist learning approach practices on classroom management. Elementary Education Online, 7(3): 664-679. 